\title{
Pentingnya Pelaksanaan Konsep Dasar K3 Di Rumah Sakit
}

\author{
Sri Rezeki Silalahi
}

\author{
srisilalahi2604@gmail.com
}

\section{LATAR BELAKANG}

Kesehatan dan Keselamatan Kerja (K3) merupakan salah satu isu penting di dunia kerja saat ini termasuk di lingkungan rumah sakit. Rumah Sakit merupakan tempat kerja yang sarat dengan potensi bahaya kesehatan dan keselamatan kerja. Rumah sakit yang merupakan sarana kesehatan yang menyelenggarakan pelayanan kesehatan, tempat berkumpulnya orang sehat dan sakit memiliki risiko kemungkinan terjadinya gangguan kesehatan dan penularan penyakit sangat tinggi. Berbagai penelitian menunjukan bahwa prevalensi gangguan kesehatan yang terjadi di fasilitas kesehatan lebih tinggi dibandingkan tempat kerja lainnya. Angka kecelakaan kerja di rumah sakit juga lebih tinggi dibandingkan tempat kerja lainnya dan sebagian besar diakibatkan oleh perilaku yang tidak aman.

Di Rumah Sakit mempunyai risiko yang berasal dari faktor fisik, kimia, biologi, ergonomi dan psikososial, variasi, ukuran, tipe dan kelengkapan Rumah Sakit menentukan tingkat risiko K3. Beberapa contoh kecelakaan kerja di Rumah Sakit yang sering terjadi adalah tertusuk jarum, terkilir, sakit pinggang, tergores, terpotong, luka bakar, penyakit infeksi dan lain-lain. Oleh karena itu, rumah sakit yang merupakan tempat pemberi pelayanan diantaranya pelayanan medik, pelayanan penunjang medik, pelayanan perawatan, pelayanan rehabilitasi, pencegahan dan peningkatan kesehatan, sebagai tempat pendidikan, pelatihan medik dan para medik, sebagai tempat penelitian, pengembangan ilmu dan teknologi bidang kesehatan dituntut mempu memberikan pelayanan dan pengobatan yang bermutu, Rumah Sakit juga harus mampu melaksanakan dan mengembangkan program Kesehatan dan Keselamatan Kerja di Rumah Sakit (K3RS) seperti yang tercantum dalam buku Standar Pelayanan Rumah Sakit dan terdapat dalam instrumen akreditasi Rumah Sakit. Dalam penanggulangan bahaya resiko di rumah sakit perlu Penerapan standar manajemen keselamatan dan kesehatan kerja Rumah Sakit merupakan bentuk upaya mengurangi risiko kecelakaan kerja dan penyakit akibat kerja di Rumah Sakit. 


\section{METODE}

Jurnal ini menggunakan metode literatur review dari berbagai sumber seperti buku, referensi jurnal dan juga membandingkan beberapa jurnal yang berhubungan dengan pentingnya pelaksanaan konsep dasar K3 di rumah sakit. Dari analisa berbagai jurnal yang digunakan untuk mengetahui betapa pentingnya pelaksanaan konsep dasar K3 di rumah sakit. Pengolahan jurnal dilakukan dengan metode membandingkan beberapa jurnal yang berkaitan dengan pentingnya pelaksanaan konsep dasar K3 di rumah sakit.

\section{HASIL}

Rumah sakit merupakan institusi pelayanan kesehatan yang menyelenggarakan pelayanan kesehatan perorangan secara paripurna. Rumah sakit termasuk tempat kerja dengan berbagai potensi bahaya yang dapat menimbulkan resiko atau dampak terhadap kesehatan dan keselamatan kerja. Kegiatan di Rumah Sakit mempunyai risiko berasal dari faktor fisik, kimia, biologi, ergonomi dan psikososial, variasi, ukuran, tipe dan kelengkapan Rumah Sakit. Bahaya potensial tersebut yang dapat menyebabkan penyakit akibat kerja (PAK) terjadi di rumah sakit, hal tersebut berkaitan dengan faktor biologi (kuman patogen yang umumnya berasal dari pasien), faktor kimia (pemaparan dalam dosis kecil namun terus menerus seperti antiseptik pada kulit, gas anestesi pada hati), faktor ergonomi (tata cara duduk, tata cara mengankat pasien), faktor fisik dalam dosis kecil yang terus menerus (suhu udara panas, listrik tegangan tinggi, dan radiasi), faktor psikologis ( hubungan kerja antar karyawan atau atasan serta tatacara kerja di kamar bedah, dibagian penerimaan pasien, di unit gawat darurat dan ruang perawatan.) Resiko ini tidak hanya untuk para pelaku langsung yang bekerja di rumah sakit namun pasien, pengunjung, masyarakat yang berada di sekitar lingkungan rumah sakit. Kecelakaan kerja juga menjadi salah satu masalah urgen di lingkungan rumah sakit. Hal ini diakibatkan karena rumah sakit merupakan suatu unit pelayanan kesehatan yang memberikan pelayanan pada semua bidang dan jenis penyakit.

Dalam rangka mewujudkan penyelenggaraan keselamatan dan kesehatan kerja rumah sakit yang efektif, efisien, terpadu, berkesinambungan maka diperlukan suatu managemen penyelenggaraan kesehatan dan kerja rumah sakit, dimana kelancaran dan implementasi kesehatan dan keselamatan kerja ini sangat diperlukan oleh rumah sakit dalam rangka mensukseskan akreditasi rumah sakit. Oleh sebab itu rumah sakit dituntut untuk dapat menyediakan dan menerapkan suatu upaya agar semua sumber daya manusia yang ada di rumah sakit dapat terlindungi, baik dari penyakit maupun kecelakaan akibat kerja. 


\section{PEMBAHASAN}

Kesehatan kerja merupakan suatu unsur kesehatan yang berkaitan dengan lingkungan kerja dan pekerjaan, yang secara langsung maupun tidak langsung dapat mempengaruhi efisiensi dan produktivitas kerja. Sedangkan, keselamatan kerja merupakan suatu sarana utama untuk mencegah terjadinya kecelakaan kerja yang dapat menimbulkan kerugian berupa luka atau cidera, cacat atau kematian, kerugian harta benda, kerusakan peralatan atau mesin dan kerusakan lingkungan secara luas. Jadi Kesehatan dan Keselamatan Kerja (K3) merupakan suatu upaya perlindungan kepada tenaga kerja dan orang lain yang memasuki tempat kerja terhadap bahaya dari akibat kecelakaan kerja. Tujuan K3 adalah mencegah, mengurangi, bahkan menihilkan resiko penyakit dan kecelakaan akibat kerja (KAK) serta meningkatkan derajat kesehatan para pekerja sehingga produktivitas kerja meningkat. Tujuan Kesehatan dan keselamatan kerja juga menurut Undang Undang No 1 tahun 1970 ialah melindungi dan menjamin keselamatan tenaga kerja dan orang lain di tempat kerja, menjamin setiap produksi dapat digunakan secara aman dan efisien, dan meningkatkan kesejahteraan dan produktivitas nasional.

Dalam Undang-Undang Republik Indonesia Nomor 36 Tahun 2009 Tentang Kesehatan, upaya kesehatan kerja ditunjukkan untuk melindungi pekerja agar hidup sehat dan terbebas dari gangguan kesehatan serta pengaruh buruk yang diakibatkan oleh pekerjaan sehingga sudah seharusnya pihak pengelola RS menerapkan upaya-upaya K3 di RS. K3 termasuk sebagai salah satu standar pelayanan yang dinilai di dalam akreditasi RS, disamping standar pelayanan lainnya. Berdasarkan peraturan pemerintah Republik Indonesia No. 50 Tahun 2012 tentang penerapan sistem manajemen keselamatan dan kesehatan kerja (SMK3) pada lampiran 1 pedoman penerapan SMK3 wajib melaksanakan perencanaan K3 yang didalamnya berisi identifikasi potensi bahaya, penilaian dan pengendalian risiko.Identifikasi Bahaya (Hazards Identification), Penilaian Risiko (Risk Assessment) dan Pengendalian Risiko (Risk Control) atau yang disingkat HIRARC merupakan suatu elemen pokok dalam sistem manajemen Keselamatan dan Kesehatan Kerja yang berkaitan dengan upaya pencegahan dan pengendalian bahaya. Keseluruhan proses dari HIRARC yang disebut juga dengan manajemen risiko (risk management), kemudian akan menghasilkan dokumen HIRARC yang sangat berguna untuk mencegah terjadinya kecelakaan kerja. Pelaksanaan Keselamatan dan Kesehatan Kerja (K3) adalah salah satu bentuk upaya untuk menciptakan tempat kerja yang aman, sehat, bebas dari pencemaran lingkungan, sehingga dapat mengu- 
rangi dan bebas dari kecelakaan kerja dan penyakit akibat kerja yang pada akhirnya dapat meningkatkan efisiensi dan produktivitas kerja.

Dalam Undang-Undang Nomor 36 Tahun 2009 tentang Kesehatan, Pasal 165 : pengelola tempat kerja wajib melakukan segala bentuk upaya kesehatan melalui upaya pencegahan, peningkatan, pengobatan, dan pemulihan bagi tenaga kerja. Berdasarkan pasal tersebut maka pengelola tempat kerja di Rumah Sakit mempunyai kewajiban untuk menyehatkan para tenaga kerjanya. Salah satunya adalah melalui upaya kesehatan kerja disamping keselamatan kerja. Rumah Sakit harus menjamin kesehatan dan keselamatan baik terhadap pasien, penyedia layanan atau pekerja maupun masyarakat sekitar dari berbagai potensi bahaya di Rumah Sakit. Oleh karena itu, Rumah Sakit dituntut untuk melaksanakan Upaya Kesehatan dan Keselamatan Kerja (K3) yang dilaksanakan secara terintegrasi dan menyeluruh sehingga risiko terjadinya Penyakit Akibat Kerja (PAK) dan Kecelakaan Akibat Kerja (KAK) di Rumah Sakit dapat dihindari. Penyakit akibat kerja di rumah sakit dapat menyerang semua tenaga kerja baik medis maupun non medis (Anies, 2005). Sehingga sasaran utama K3RS adalah tenaga medis, tenaga non medis, pasien, pengunjung / pengantar pasien, serta masyarakat sekitar Rumah Sakit. Pelaksanaan K3 juga berkaitan dengan citra dan kelangsungan hidup RS. Manajemen adalah proses perencanaan, pengorganisasian, pengarahan dan pengawasan usaha para anggota organisasi dan pengguanaan sumber daya organisasi lainnya agar mencapai tujuan organisasi yang telah ditetapkan.

Kementerian Kesehatan Republik Indonesia mewajibkan dilaksanakannya akreditasi RS dengan tujuan untuk meningkatkan pelayanan RS di Indonesia. Standar akreditasi yang digunakan saat ini akan menekankan pada pelayanan berfokus pada pasien serta kesinambungan pelayanan dan menjadikan keselamatan pasien sebagai standar utama serta melibatkan seluruh petugas dalam proses akreditasi. Keselamatan kerja juga memiliki beberapa unsur unsur penunjang yaitu unsur unsur keamanan dan kesehatan kerja, teliti dalam bekerja, melaksanakan prosedur kerja dengan memperhatikan keamanan dan keselamatan kerja. Kesehatan keselamatan dan keamanan kerja merupakan upaya perlindungan bagi tenaga kerja agar selalu dalam keadaan sehat dan selamat selama bekerja di tempat kerja. Pelaksanaan konsep dasar kesehatan dan keselamatan kerja juga harus memberikan pengaman bagi peralatan berbahaya, menyiapkan alat pelindung diri (APD) dan bahan baku yang aman dan proses kerja yang ergonomis. Dalam penyelenggaraan upaya kesehatan di Rumah Sakit harus dilengkapi dengan kebijakan tertulis tentang pengelolaan kesehatan dan keselamatan kerja rumah sakit, pedoman dan standar prosedur operasional 
kesehatan dan keselamatan kerja, perizinan sesuai dengan peraturan yang berlaku, sistem komunikasi baik, Sertifikasi, Program pemeliharaan, Alat Pelindung Diri (APD) yang memadai, sistem alarm sistem pendeteksi api/kebakaran dan penyediaan alat pemadam api atau kebakaran, rambu-rambu Kesehatan dan keselamatan kerja seperti rambu larangan dan rambu penunjuk arah, fasilitas sanitasi yang memadai dan memenuhi persyaratan kesehatan, fasilitas penanganan limbah padat, cair dan gas. Setiap lingkungan kerja harus dilakukan pemantauan atau monitoring kualitas lingkungan kerja secara berkala dan berkesinambungan.

Rumah Sakit harus membuat peta/denah lokasi/ruang/alat yang dianggap berisiko dan berbahaya dengan dilengkapi simbol-simbol khusus untuk daerah/tempat/area yang berisiko dan berbahaya. Rumah Sakit harus mengadakan kalibrasi internal dan kalibrasi legal secara berkala terhadap sarana, prasarana dan peralatan yang disesuaikan dengan jenisnya. Rumah Sakit juga diwajibkan melaksanakan kegiatan evaluasi, pencatatan dan pelaporan program pelaksanaan Kesehatan dan keselamatan kerja sarana, prasarana dan peralatan Rumah Sakit. Dalam melakukan K3 juga perlu peran perawat. Notoadmodjo (2010)menambahkan bahwa ada berbagai cara yang dapat dilakukan untuk meningkatkan persepsi, pengetahuan dan sikap perawat dalam menjaga kesehatan dan keselamatan selama bekerja, diantaranya dengan memberikan promosi kesehatan dan pelatihan tentang K3 sehingga hal ini diharapkan mampu merubah perilaku perawat menjadi lebih baik.Selain faktor internal, faktor eksternal juga sangat mempengaruhi perilaku perawat dalam penerapan manajemen K3 di rumah sakit. Peneliti berasumsi bahwa ada banyak faktor yang dapat menentukan perubahan perilaku perawat dari segi faktor eksternal diantaranya pengalaman. Oleh karena itu, maka dapat simpulkan bahwa potensi bahaya di Rumah Sakit sangat tinggi sehingga dibutuhkan langkah manajemen untuk mengontrol seluruh tenaga kerja supaya terhindar dari hal hal yang tidak diharapkan. Penerapan Manajemen Keselamatan dan Kesehatan Kerja Rumah Sakit (MK3RS) menjadi sangat penting dalam rangka melindungi seluruh pekerja dari kecelakaan kerja dan penyakit akibat kerja di Rumah Sakit dan sasaran utama K3RS adalah tenaga medis, tenaga non medis, pasien, pengunjung / pengantar pasien, serta masyarakat.

\section{PENUTUP}

\section{Kesimpulan}

Kesehatan dan keselamatan kerja merupakan salah satu unsur terpenting dalam bekerja. Kesehatan dan keselamatan kerja di rumah sakit dapat berjalan dengan baik jika memiliki fasilitas yang memadai dan pengetahuan pekerja yang cukup. Dalam kesehatan dan 
keselamatan kerja perlu pelaksanaan K3RS mengenai kebijakan pemerintah tentang RS di Indonesia diantaranya untuk meningkatkan akses, keterjangkauan, dan kualitas pelayanan kesehatan yang aman di rumah sakit.

\section{Saran}

\section{Bagi Rumah Sakit}

Bagi rumah sakit sebaiknya selalu dapat memberikan dukungan dan memfasilitasi para perawat untuk dapat meningkatkan pengetahuan dengan pelatihan serta melatih keterampilannya sehingga dapat bekerja dengan lebih aman.

\section{Bagi Perawat}

Perawat/petugas perlu melakukan pekerjaan sesuai standar prosedur operasional (SPO) yang ada dengan baik dan benar, dapat bekerja dengan hati-hati, fokus, dan selalu mengutamakan K3 (Keselamatan dan Kesehatan Kerja) dalam bekerja. 


\section{REFERENSI}

Djadmiko Risman Dewi. (2016). Keselamatan dan Kesehatan Kerja. Yogyakarta: Deepublish Ibrahim Hasbi, Dwi Santy Damayanti, Munawir Amansyah, Sunandar. (2017). Gambaran Penerapan Standar Managemen Keselamatan dan Kesehatan Kerja Rumah Sakit Umum Daerah Haji Makassar. Public Health Science Journal

http://journal.uin-alauddin.ac.id/

Indragiri Suzana, Triesda Yuttya. (2018). Management Resiko K3 Menggunakan Hazard Identification Risk Assesment and Risk Control (HIRARC). Jurnal kesehatan Vol 9(1) http://jurnal.stikescirebon.ac.id/

Ivana Azza, Baju Widjasena, Siswi Jayanti. (2014). Analisa Komitmen Management Rumah Sakit (RS) Terhadap Keselamatan Dan Kesehatan Kerja (K3) Pada RS Prima Medika Pemalang. Jurnal Kesehatan Masyarakat Vol2(1)

http://ejournal3.undip.ac.id/

Nazirah Riska, Yuswardi. (2017). Perilaku Perawat Dalam Penerapan Managemen Kesehatan Dan Keselamatan Kerja (K3) Di Aceh. Idea Nursing Journal Vol 8(3)

http://jurnal.unsyiah.ac.id/INJ/article/view/9578

Irzal.(2016). Dasar Dasar Kesehatan dan Keselamatan Kerja. Jakarta: Kencana

Oktavia Widiwati Rinjani, Diana Nerawati, Ernita Sari. (2018). Penerapan Pelayanan Kesehatan dan Keselamatan Kerja Pada Perawat IGD Rumah Sakit Umum DR. Wahidin Sudiro Husido Mojokerto Tahun 2017.

http://journal.poltekkesdepkes-sby.ac.id/

Simamora, R. H. (2011). ROLE CONFLICT OF NURSE RELATIONSHIP WITH PERFORMANCE IN THE EMERGENCY UNIT OF HOSPITALS RSD DR. SOEBANDI JEMBER. The Malaysian Journal of Nursing, 3(2), 23-32.

Suhariono. (2019). Pengelolaan Keselamatan dan Kesehatan Kerja (K3) di Rumah Sakit. Jawa Timur: Uwais Inspirasi Indonesia.

Yuliani HR. (2012). E-Learning Keselamatan Dan Kesehatan Kerja (K3). Yogyakarta: Deepublish

Yuliandi, C.D.(2019). Penerapan Keselamtan dan Kesehatan Kerja (K3) di Lingkungan Kerja Balai Insemina Buatan (BIB) Lembang. Lembang : Manajerial 
